\title{
TIMELINES EM “COISA № 5” DE MOACIR SANTOS
}

\section{TIMELINES IN “COISA No 5” BY MOACIR SANTOS}

Fábio Lima Marinho Gomes ${ }^{1}$ Universidade Estadual do Paraná fabiolimamgomes@gmail.com 


\section{Resumo}

Este artigo apresenta parte da pesquisa de conclusão de curso sobre a presença de timelines em três peças do álbum "Coisas" (1965), de Moacir Santos, defendida na FAP/UNESPAR, em 2019. O estudo tem como foco o aspecto rítmi$\mathrm{co}$, destacando a verticalidade das composições, as texturas polirrítmicas e os contrastes entre as ideias musicais articuladas por Moacir Santos. Este trabalho debruça-se sobre a peça "Coisa $n^{\circ} 5$ " e demonstra a influência marcante da música de matriz africana por meio das timelines, tendo como base a gravação original e o livro de partituras "Coisas: Cancioneiro Moacir Santos". Dessa forma, as análises demonstram que as timelines identificadas são customizadas, criando combinações com a função de orientar a estrutura rítmica da peça.

Palavras-chave: Moacir Santos. Coisa $n^{\circ}$ 5. Timeline. Análise Musical.

\section{Abstract}

This paper is part of the undergraduate research on the use of timelines in three pieces of the album "Coisas" (1965), by Brazilian composer Moacir Santos, presented at FAP/UNESPAR (Curitiba, Brazil), in 2019. The present study is based on the rhythmic aspect, drawing attention to the vertical perspective of the pieces, the polyrhythmic textures and the contrasts between the musical ideas articulated by Moacir Santos. The aim is to demonstrate, especially in "Coisa no 5", the strong influence of African matrix through timelines, based on the original recording and the score book "Coisas: cancioneiro Moacir Santos". Thus, the analyses show that the identified timelines are customized, creating combinations with the function of guiding the rhythmic structure of the piece.

Keywords: Moacir Santos. Coisa № 5. Timeline. Musical Analysis.

\footnotetext{
1 Fábio Marinho é músico, professor e pesquisador com foco na música popular brasileira. Bacharel em Música Popular (FAP/Unespar), Bacharel em Humanidades (IHAC/Ufba) e possui Qualificação Profissional em Música Afro Baiana (CFA/Funceb).
} 


\section{Introdução}

A obra de Moacir Santos (1926-2006) se apresenta de forma complexa e desafiadora, sendo gradualmente valorizada pela comunidade musical e pelo público em geral nas últimas décadas. Com uma carreira multifacetada, o músico despertou variados olhares acadêmicos e diversas pesquisas foram feitas em nível de pós graduação, principalmente após o seu falecimento (FRANÇA, 2007; DIAS, 2010; VICENTE, 2012; BONETTI, 2014). O álbum "Coisas" (1965) é a sua produção fonográfica de maior relevância e foi a única lançada no Brasil, pois a partir daí o compositor desenvolveu sua trajetória nos Estados Unidos. Este artigo deriva-se de uma pesquisa mais ampla em formato de monografia (GOMES, 2019) a qual objetivou-se analisar a presença de timelines em três faixas do referido álbum². Aqui, busca-se uma análise mais criteriosa sobre o aspecto rítmico na terceira faixa: a peça "Coisa no 5", que posteriormente teve uma versão com letra in- titulada "Nanã" e acabou sendo muito difundida. Dessa forma, a maior motivação deste estudo é entender como os elementos rítmicos são organizados na estrutura composi- cional por meio das timelines. Essa ferramenta possibilita um aprofundamento analítico da peça, dando foco na sua relação com outros elementos musicais, sobretudo a melo- dia, uma vez que são notáveis os traços da música de matriz africana em todo o álbum "Coisas". Por sinal, a música popular brasileira é baseada, em grande parte, na música de origem africana (SANDRONI, 2001) e, por isso, as timelines estão presentes na maioria do seu repertório constituindo a estrutura sonora (OLIVEIRA PINTO, 1999-2001).

De acordo com a literatura, os conceitos embrionários de timeline advêm de reflexões acadêmicas baseadas nas experiências de pesquisadores ao se debruçarem sobre a música da costa ocidental africana e sua complexidade rítmica (JONES, 1959; NKETIA, 1963; KUBIK, 1972; AROM, 1991) ${ }^{3}$. Assim, essas concepções de timeline foram elaboradas visando o entendimento estrutural e analítico ao invés de serem um suporte ou técnica para a execução musical. Ou seja, os instrumentistas presentes nas gravações e/ ou performances (incluindo a dança, além da música) observadas pelos pesquisadores não tinham em mente as timelines, assim como não pensaram em rítmica aditiva, polirritmia, hemíola e síncope (AGAWU, 2006; FREITAS, 2010). Esses e outros termos são conceitos musicológicos de herança europeia, que tiveram suas elaborações partindo do princípio de que a estrutura musical, e todos os seus elementos (harmonia, melodia, ritmo, forma etc.), encontram regularidade no repertório tradicional da Europa. O autor desta investigação está ciente das questões que a análise estrutural de uma peça com elementos musicais de matriz africana pode suscitar, e por isso há uma abordagem crítica com relação à teoria musical de cunho eurocêntrico.

O debate teórico apresentado na primeira parte do texto contribuirá para uma noção abrangente do conceito de timeline, não se restringindo ao viés estruturalista

2 A monografia foi apresentada como trabalho de conclusão do curso de Bacharelado em Música Popular (FAP/UNESPAR-Campus de Curitiba II), orientada pelo Prof. Dr. Luciano Chagas Lima.

3 Conforme será visto mais adiante, Nketia (1963) foi o primeiro a utilizar o termo timeline. Porém, Jones (1959) utilizou o termo "african signature tune" para se referir a determinados padrões rítmicos que posteriormente foram denominados timeline, a exemplo do standard pattern - objeto central do artigo Structural Analysis or Cultural Analysis? Competing Perspectives on the "Standard Pattern" of West African Rhythm (2006), de Agawu. 
e musicológico, considerando aspectos sociais, históricos e culturais (AGAWU, 2006; MENEZES, 2018). Portanto, a timeline, na condição conceitual problematizada, foi eleita como ferramenta metodológica de análise, ainda que não haja vestígios encontrados de qualquer depoimento sobre o conhecimento da ideia geral de timeline por parte do compositor. Esse ponto leva à questão da intencionalidade na análise musical: Moacir Santos sabia o que era timeline e, de fato, utilizou-a em composições de forma consciente? Se não, ainda assim é possível desenvolver o conceito de timeline aplicando na análise de estrutura rítmica? Entende-se que mesmo quando há depoimento de intencionalidade, o pensamento analítico pode trilhar outros caminhos interpretativos, enfraquecendo a ideia de que a intenção do compositor orienta a uma essência na peça musical a ser explicada e revelada por meio da análise. Em How We Get Out of Analysis, and How to Get Back In Again (2005), Agawu argumenta, embasando-se no pensamento analítico de Theodor Adorno (1903-1969) ${ }^{4}$ :

O analista não deve ser distraído pela questão da intencionalidade, como fazem os céticos ao se perguntarem se o compositor estava consciente das relações desenterradas pelo analista. A análise não é mera descrição, nem é limitada por uma consideração de todos ou da totalidade; poderia, com a mesma legitimidade, preocupar-se com partes ou fragmentos. E cada análise deve produzir um resultado exclusivo para o trabalho; deve trazer à tona o problema, ou - como diríamos hoje, talvez - a problemática única de cada obra (AGAWU, 2005, p. 272, tradução nossa) $)^{5}$.

Por outro lado, a intenção do compositor em criar a trilha musical para uma procissão de negros no contexto sócio histórico da escravidão, inserida em longa metragem servindo de base para a gravação do álbum "Coisas", é usada como dado importante na análise, pois é possível fazer conexões com a influência da música de matriz africana na peça ${ }^{6}$. Assim, a proposta analítica articulada neste trabalho leva em consideração esse mote para investigar como Moacir Santos estruturou a rítmica por meio das timelines em "Coisa $n^{\circ} 5$ ". O que se faz neste artigo é uma análise com foco no aspecto rítmico, mas também incorporando elementos de ordem melódica, enfocando na parte $A$, que possam auxiliar em uma melhor compreensão da peça. Com isso, priorizou-se a verticalidade da composição, os contrastes entre as ideias musicais articuladas por Moacir Santos e as texturas polirrítmicas ${ }^{7}$. Antes disso, há um breve resumo biográfico do compositor, uma ampla discussão conceitual sobre timeline e uma contextualização do ál-

4 Theodor Ludwig Wiesengrund-Adorno foi um sociólogo, filósofo, musicólogo e compositor alemão do século XX que pertenceu à Escola de Frankfurt, versando sobre indústria cultural e música popular.

5 Original: "The analyst must not be distracted by question of intentionality, as when sceptics wonder whether the composer was conscious of relationships unearthed by the analyst. Analysis is not mere description, nor is it bound by a consideration of wholes or of totality; it could just as legitimately concern itself with parts or fragments. And each analysis must produce a result unique to the work; it must bring out the problem, or - as we would say today, perhaps - the unique problematic of each work".

60 longa metragem referido é "Ganga Zumba" (1964), de Carlos Diegues, e será abordado posteriormente junto com o depoimento de Moacir Santos sobre aintenção.

70 termo verticalidade refere-se à uma visão das interações rítmicas presentes na peça, do topo da partitura até o último instrumento na grade. Por isso, as análises possuem como um dos critérios a perspectiva, ou o olhar, vertical sobre as ideias composicionais. 
bum "Coisas", elucidando aspectos que nortearam o processo composicional. Em 2005, Mário Adnet e José Nogueira realizaram um importante trabalho de reconstrução das partituras originais do álbum "Coisas", as quais desapareceram com o fim do selo Forma, resultando na publicação do livro de partituras "Coisas: cancioneiro Moacir Santos" (2005), material que é fonte deconsulta.

\section{Moacir Santos}

Moacir José dos Santos nasceu em 1926 entre os municípios de Serra Talhada (antiga Vila Bela), Flores, São José do Belmonte e Bom Nome, no sertão pernambucano. De acordo com a pesquisa biográfica realizada por Dias (2010), até os 16 anos, aproximadamente, o músico não possuía um documento que comprovasse sua data de nascimento. Foi batizado na Capela de Santo Antônio do município de Bom Nome com o nome de "Muacy". Negro, órfão da mãe aos 3 anos de idade e com um pai ausente, Moacir foi cursar o ginásio no município de Flores, a $340 \mathrm{~km}$ de Recife. Já como integrante da Banda Municipal, Moacir recebeu o seu primeiro cachê tocando trompa nas festividades religiosas. O período entre os 11 e 14 anos de idade foi considerado por ele como a fase áurea de sua vida, quando tocou em vários eventos nas cidades vizinhas. Sua intuição o levava a "apanhar sua estrela" - termo usado pelo músico em depoimento - algo semeIhante a uma estrela guia que norteia os caminhos de uma pessoa em busca de realização pessoal, sentido de vida, vocação (DIAS, 2010, p. 42).

Durante a juventude, Moacir Santos percorreu várias cidades brasileiras exercendo atividades musicais, passando pelos estados da Bahia, Paraíba, Ceará, São Paulo e Rio de Janeiro. Na cidade do Rio de Janeiro foi onde o compositor passou a maior parte do seu tempo trabalhando com música, tendo como destaque o emprego na Rádio Nacional como arranjador, e posteriormente como maestro. Em 1967, dois anos após a gravação do álbum "Coisas", Moacir Santos muda-se para os Estados Unidos, onde foi trabalhar com trilhas musicais para filmes na Califórnia e gravou mais quatro álbuns: "Maestro" (Blue Note/1972), "Saudade" (Blue Note/1974), "Carnival of Spirits" (Blue Note/1975) e "Opus 3 n० 1" (Discovery Records/1979).

Em 1998, os músicos cariocas Mario Adnet e Zé Nogueira começaram o projeto "Ouro Negro", que se concretizou a partir do lançamento do CD duplo em 2001, através do selo MP,B e distribuído pela Universal, sob patrocínio da Petrobras. O repertório inclui músicas de toda a carreira do compositor pernambucano, inclusive as "Coisas", com exceção da "Coisa n n $^{\circ}$ ". Impossibilitado de tocar por conta de problemas de saúde, Moacir voltou ao Brasil e acompanhou as gravações do CD, fato que foi muito importante na condução dos ensaios. As partituras das "Coisas", que se perderam após o fechamento do selo Forma, foram reescritas por Mario Adnet e Zé Nogueira e revisadas pelo compositor (DIAS, 2010, p. 154). Anos depois, os músicos cariocas se dedicaram à gravação do CD "Choros e Alegria", lançado pelo selo Biscoito Fino, em 2005. O álbum reúne choros antigos do jovem Moacir juntamente com músicas não gravadas compos- 
tas na época em que morava na cidade de Pasadena. A dupla Mario Adnet e Zé Nogueira também lançou o "Cancioneiro Moacir Santos" (Jobim Music, 2005), que possui três volumes com partituras do "Ouro Negro", das "Coisas" e do álbum "Choros e Alegria". A publicação de todos esses trabalhos foi crucial para a revalorização da obra do compositor em solo brasileiro.

Com a saúde cada vez mais debilitada, Moacir Santos faleceu no dia 6 de agosto de 2006, na cidade de Pasadena, estado da Califórnia, nos Estados Unidos. Noticiado na imprensa nacional e internacional, seu falecimento foi de grande perda para a comunidade musical: a estrela de "Muacy" foi brilhar em outro lugar.

\section{Timeline}

O termo timeline foi incialmente usado pelo etnomusicólogo ganense Joseph Hanson Kwabena Nketia (1921-2019) na década de 1960, quando estudava a rítmica musical da costa ocidental africana, significando um "ponto de referência constante pelo qual a estrutura da frase de uma música, bem como a organização métrica linear das frases são guiadas" (NKETIA, 1963, tradução nossa) ${ }^{8}$. A expressão obteve grande repercussão no estudo da música africana (KUBIK, 1972; AROM, 1991; AGAWU, 2006; AGAWU, 2016) e da música afro brasileira (OLIVEIRA PINTO, 1999-2001; SANDRONI, 2001; LEITE, 2017; RIBEIRO, 2017; MENEZES, 2018), e com isso a literatura demonstra uma variedade de conceitos sobre timeline. Esta seção objetiva expor algumas formulações conceituais e debater os pontos relevantes a serem observados na análise. $O$ etnomusicólogo africano Kofi Agawu, também nascido em Gana, propõe uma definição de timeline em palestra organizada pela Library of Congress, nos Estados Unidos ${ }^{9}$. Intitulada Rhythmic Imagination in African Music, a palestra apresenta os pontos centrais do livro The African Imagination in Music (2016), de sua própria autoria. Na minutagem 36'57', Agawu diz:

A timeline é um padrão rítmico de curta duração que é repetido na forma de um ostinato, através de uma batida de percussão específica (...). Normalmente atreladas ao uso de sinos, baquetas ou pedra, as timelines, muitas vezes, projetam uma forma distinta e até memorável. Embora existam padrões percussivos de pulsação imutável, a maioria das timelines exibe pelo menos dois valores de modo contrastantes, um longo e um curto. Isso, a propósito, é outro sinal do impulso minimalista que é difundido na criatividade africana. Embora a função dos padrões timeline seja comparada, às vezes, com a de um metrônomo, há uma diferença significativa. Diferindo do metrônomo, que demarca o tempo e com isso ajuda a localizar a 'parede de ataques sem acento', as timelines esculpem o tempo, elas são parte integrante da música. Cada timeline é, em princípio, estru-

8 Original: "A constant point of reference by which the phrase structure of a song as well as the linear metrical organization of phrases are guided". 
turalmente dependente de uma fundação metronômica anterior (AGAWU, 2017, informação verbal, tradução nossa) ${ }^{10}$.

Percebe-se nesta definição de Agawu as seguintes características da timeline: a) padrão rítmico de curta duração, em forma de ostinato, tocado por instrumentos percussivos $^{11}$; b) pulsação constante com dois valores de duração contrastantes; c) possui função distinta daquela do metrônomo, uma vez que integra a música ao invés de ajudar a localizar o tempo de maneira externa à música. Em seguida, serão apresentados alguns conceitos formulados por pesquisadores brasileiros acompanhados de discussões.

Oliveira Pinto (1999-2001) busca sistematizar as estruturas sonoras da música afro brasileira, que possui como alicerce a música de matriz africana. Segundo o autor, as tradições musicais africanas se alastraram pelo continente americano originando, em combinação com as tradições musicais dos povos originários, uma vasta lista de gêneros populares afro americanos, na qual o blues, a rumba, o reggae, o jazz, o son cubano, a milonga, a salsa e o tango estão presentes. Com enfoque nas estruturas sonoras, Oliveira Pinto, após os resultados de pesquisa da musicologia africana em convergência com as pesquisas feitas no Brasil, relata: "encontramos estruturas sonoras que perduraram durante sua história (no Brasil) e que marcam as músicas afro-brasileiras" (OLIVEIRA PINTO, 1999-2001, p.91). Uma destas estruturas sonoras é a timeline, que o autor traduz como "linha rítmica" e nos apresenta exemplos da sua inserção no samba e no candomblé, duas importantes manifestações da música afro brasileira. Segundo ele, "os time-line-pattern estão inseridos em uma grande variedade de repertórios de música brasileira e funcionam como linha rítmica de orientação para as demais partes da música na sua sequência temporal" (OLIVEIRA PINTO, 1999-2001, p.95).

Menezes (2018), ao investigar como se deu a influência da música africana no Brasil, considera a formação do sistema atlântico escravista na colonização do país como alicerce desse entendimento, em que a diáspora africana envolveu a convivência forçada de povos distintos. A historicidade é um elemento fundamental para acompreensão desse fenômeno, e por isso é preciso combater as tendências de descolamento da análise musical, em geral, com relação à contextualização social, cultural e histórica de perspectiva crítica. Entendendo esse processo, o autor trata da formação do samba urbano carioca, especificamente sobre seus padrões rítmicos, a partir da coexistência de diferentes práticas musicais ali existentes no período colonial projetada no século XX. Por isso, não há como tratar de timeline sem mencionar esse passado e sem considerar questões culturais africanas, tais como a tradição, a oralidade e a dança.

10 Original: "A timeline is a rhythmic pattern of modest lenght that is repeated in a manner of austinato throughout a particular dance drumming (...). Normally entrusted to the bell or custonet or sticks or stone, timelines often project a distinct perhaps even memorable shape. Although there are bells and sticks patterns made up of unchanging pulsation, the majority of timelines display at least two contrasting node values, a long and a short. This, by the way, is another sign of the minimalist impulse that is widespread in african creativity. Although the function of timeline patterns is sometimes likened to that of a metronome, there is a significant difference. Unlike metronomes wich mark time and thus help to locate patterns against a wall of accentless strikes, timelines carve time, they are integral to the music. Each individual timeline is in principle structurally dependent on prior metronomic foundation".

11 Ostinatoé uma palavra italiana que significa obstinado, em tradução literal para o português. Como termo musical, traza ideia de repetição de uma frase rítmica e/ou melódica. 
Embora a timeline se mantenha como elemento estruturante da música afro brasileira, Oliveira Pinto constata que "no Brasil houve uma ressignificação do time-line africano em relação ao seu novo meio musical (...). Há momentos em que certas batidas do time-line são suprimidas, como se pode verificar com frequência na MPB" (OLIVEIRA PINTO, 1999-2001, p.97). Neste caso, o autor se refere aos momentos, principalmente na prática do samba, em que a timeline não é tocada exclusiva e integralmente por um determinado instrumento, sendo distribuída através das diferentes partes instrumentais e funcionando como referência interna para os músicos. Segundo ele, o fato de o padrão rítmico da timeline não estar sendo "marcado com a batida de um tamborim, não significa que a fórmula não esteja presente no fazer musical. É mentalizada pelos músicos e inerente às diferentes sequências instrumentais do conjunto" (OLIVEIRA PINTO, 1999-2001, p.99). ${ }^{12}$

Sandroni (2001), por sua vez, traduz o termo timeline como "linha-guia" e elabora o seguinte conceito:

Em muitos repertórios musicais da África Negra, 'linhas-guia' representadas por palmas, ou por instrumentos de percussão de timbre agudo e penetrante (como idiofones metálicos do tipo do nosso agogô), funcionam como uma espécie de metrônomo, um orientador sonoro que possibilita a coordenação geral em meio a polirritmias de estonteante complexidade. O fato é que essas 'linhas-guia' têm especial predileção por fórmulas assimétricas como as mencionadas, que são, então, repetidas em ostinato estrito, do início ao fim de certas peças (SANDRO$\mathrm{NI}, 2001$, p.31).

Desta maneira, de acordo com Sandroni a timeline: a) é produzida por instrumentos de percussão de timbre agudo; b) assemelha-se ao metrônomo, funcionando como um orientador sonoro ${ }^{13}$; c) possui, em sua maioria, fórmulas assimétricas executadas em longas repetições. No que concerne à semelhança com o metrônomo como um orientador sonoro, o autor traz a ideia de "ostinato variado", termo criado pelo etnomusicólogo franco-israelense Simha Arom. Sandroni afirma que “(...) a fórmula rítmica assimétrica ora é repetida, ora variada através de improvisações do músico responsável pela 'linha-guia'. Estas variações em muitos casos obedecem ao princípio da subdivisão, ou seja, a decomposição de valores menores (...)" (SANDRONI, 2001, p.25). Assim, a timeline, embora seja geralmente executada da mesma maneira em toda a música (ostinato estrito), não é sempre reproduzida de forma regular, podendo incorporar variações (ostinato variado).

Já com relação às fórmulas assimétricas executadas em longas repetições, o autor apresenta as expressões "cometricidade", "contrametricidade" e "síncope" para explicar as fórmulas assimétricas das timelines. As expressões "cometricidade" e "contrametricidade" são usadas por Simha Arom e por Mieczyslaw Kolinski (1901-1981), e o termo

12 A internalização da timeline pelos músicos será melhor tratada adiante através de Leite (2017).

13 A semelhança da timeline com o metrônomo pode ser lida na citação anterior de Agawu (2017) e também será abordada em detalhe mais adiante nas reflexões de Ribeiro (2017). 
"síncope" advém do sistema de notação musical europeu do século XIX. Essas expressões foram criadas para designar o tipo da articulação rítmica associada à métrica da musicalidade europeia. Ou seja, se a articulação é irregular à métrica, ela é contramétrica. Sandroni afirma: "uma articulação rítmica será dita cométrica quando ocorrer na primeira, terceira, quinta ou sétima semicolcheia do 2/4; será dita contramétrica quando ocorrer nas posições restantes, à condição de não ser seguida por nova articulação na posição seguinte" (SANDRONI, 2001, p.26-27). Para Sandroni, a "síncope" surgiu quando os compositores europeus do século XIX quiseram representar em suas partituras os ritmos africanos que ouviam, grosso modo ${ }^{14}$. Porém, esses ritmos misturam as divisões rítmicas binária e ternária enquanto a concepção rítmica europeia (de tradição clássico-romântica) é baseada na separação dessas divisões. Como o sistema de notação utilizado pelos compositores não prevê a coexistência de grupos rítmicos binários e ternários, esses ritmos foram considerados irregulares e compostos por "síncopes", por meio do recurso das ligaduras (SANDRONI, 2001, p.26). Ele explica:

Nossa teoria musical clássica prevê dois tipos de compasso, os simples e os compostos. Nos compassos simples, as unidades de tempo são binárias. Por exemplo, nos compassos $2 / 4,3 / 4$ e 4/4, a unidades de tempo são as semínimas, que, dividindo-se sempre por dois, serão equivalentes a duas colcheias ou quatro semicolcheias etc. (Os casos em que semínimas são divididas do modo ternário constituem exceções à regra, são chamados de 'quiálteras' e exigem sinalização especial). Por outro lado, nos compassos compostos, como o 6/8 ou o 9/8, as unidades de tempo são ternárias e são representadas por semínimas pontuadas (divididas portanto em três colcheias). Mas o fato é que não há compassos que misturem de modo sistemático agrupamentos de duas e de três pulsações, como semínimas e semínimas pontuadas. É precisamente esta mistura que vai desempenhar um papel muito importante nas músicas da África subsaariana (SANDRONI, 2001, p.24).

Dito isto, a assimetria presente nas timelines a que Sandroni se refere, advém do termo "imparidade rítmica" cunhado por Simha Arom. Ao estudar a música africana, Arom (1991) constatou que a combinação dos agrupamentos binários e ternários resultava sempre em um período rítmico par na soma, porém com sua estrutura interna ímpar, ou seja, assimétrica (SANDRONI, 2001, p.24).

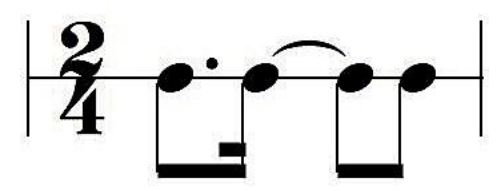

Fig. 1 - Assimetria na timeline (tresillo).

14 Para aprofundamento sobre a síncope e sua história conceitual, recomenda-se a leitura de Freitas (2010). Em artigo, 0 autor faz uma criteriosa análise histórica da síncope na tradição europeia, relacionada ao tratamento melódico/harmônico, antes de problematizar a síncope como uma espécie de DNA rítmico da música brasileira. 


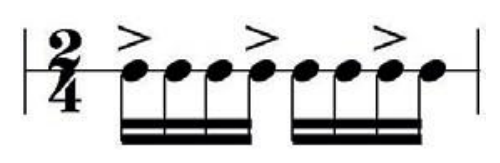

Fig. 2 - Assimetria na timeline. Período rítmico par em sua soma, com 8 pulsações internas, porém, apresenta disposição interna ímpar: $3+3+2$.

Letieres Leite (2017) ${ }^{15}$ buscou justificar a importância da timeline na música de matriz africana ao escrever sobre a aplicação do seu "Método Universo Percussivo Baiano" (UPB) na primeira turma do Laboratório Musical Rumpilezzinho ${ }^{16}$. Para se referir à timeline, ele adota o termo em espanhol "clave", oriundo do sistema musical cubano, e que literalmente significa "chave" em português, sugerindo um elemento responsável pela conexão com a estrutura rítmica da música, podendo "abrir portas" - a propósito, o termo "clave" também pode ser traduzido como truque, macete ou segredo em sentido figurado. Segundo Leite:

CLAVES - AS CHAVES RÍTMICAS: Também conhecidas como 'linhas-guia', 'time-line', 'padrão rítmico', 'toque' (nas religiões afro-brasileiras). Ao longo deste relato, seguirei adotando a denominação 'clave', pelo fato de ter me 'iniciado' com músicos cubanos nesta matéria. Em suma, 'clave' pode ser entendida como a menor porção rítmica que define não só um ritmo, como aponta para a sua localização geográfica, sua origem e percurso étnico e histórico (LEITE, 2017, p.18).

Seu interesse na complexidade rítmica da música brasileira o levou a concluir, através das suas pesquisas, que a perspectiva musical europeia (modelo dominante nas instituições de ensino) não é suficiente para explicar as peculiaridades da cultura musical nacional (LEITE, 2017, p.17). Considerando a música brasileira estruturada pelos elementos da música africana, principalmente no que tange às suas organizações rítmicas, Leite converge com as ideias de Oliveira Pinto e Sandroni, já explicitadas anteriormente. Ao afirmar que a clave é o segredo, ele diz: "percebi que nossa música (brasileira) era constituída e estruturada da mesma forma que a música cubana, inclusive pelas influências comuns de matrizes africanas, e que as claves se mantinham, mas mudavam apenas seus acompanhamentos (...)" (LEITE, 2017, p.22).

Dessa forma, Leite (2017) ressalta a importância da timeline através do processo denominado "clave consciente", originado em Cuba, aprendido com o maestro Alfredo

15 Criador, maestro, compositor, arranjador e multi-instrumentista da Orkestra Rumpilezz, grupo instrumental baiano de música matricial africana formado por percussão e sopros. Em 2019, a orquestra gravou um álbum de releituras das "Coisas", de Moacir Santos.

16 Projeto de formação musical de jovens idealizado por Letieres Leite na cidade de Salvador (BA), em 2014. Foi vencedor do edital do programa Natura Musical do respectivo ano e desenvolve atividades de prática em conjunto, arranjo, composição e história da música afro baiana. 0 diminutivo refere-se à Orkestra Rumpilezz, sugerindo uma orquestra mirim. 
De La Fé (1954) no período que morou e estudou em Viena, Áustria ${ }^{17}$. O processo da "clave consciente" envolve uma conexão entre o arranjo e a execução instrumental de um determinado conjunto musical. Segundo Leite, essa coesão é que deixa as músicas "amarradas", por meio de muito rigor rítmico visando interiorizar a timeline. O termo "amarrar" se refere ao entrosamento dos instrumentistas, que reflete a organização e a qualidade do arranjo. Já o termo "consciente" envolve o entendimento da clave por parte dos instrumentistas, na medida em que o corpo processa a informação rítmica de forma satisfatória e coerente. A transmissão oral da clave possibilita que o músico receba a informação por outro caminho, que não o do processo racional da leitura musical através de uma partitura. As claves são transmitidas e recebidas por outros sistemas de cognição, proporcionando um entendimento pelo corpo, uma "apropriação corporal" (LEITE, 2017, p.43).

Ao versar sobre a rítmica aditiva, Ribeiro (2017) discute seus componentes fundamentais: pulso, ritmo, polimetria, polirritmia, hemíola, periodicidade, timeline, entre outros. A notação musical europeia pode gerar incoerências ao tentar organizar a música de matriz africana, uma vez que esta é baseada no conceito aditivo de rítmica e não possui acentos regulares. Um exemplo é o uso equivocado de fórmulas de compasso ocidentais, que acabam gerando acentuações inexistentes. Pelo fato da timeline apresentar, necessariamente, uma estrutura interna assimétrica, sua representação relaciona-se mais com uma concepção aditiva do que divisiva. A soma de dois grupos rítmicos irregulares remonta à adição. Constata-se que o ritmo, pela lógica aditiva, necessita de uma periodicidade para existir, na qual se materializa pela acentuação do pulso. Dessa forma, a construção das timelines se dá pelas acentuações das pulsações de menor valor (elementares):

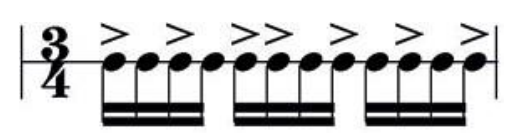

Fig. 3 - Formação da timeline por meio de acentuações em compasso ternário simples.

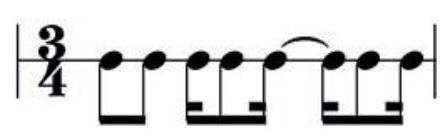

Fig. 4 - Efeito rítmico das acentuações.

17 Alfredo Manuel De La Fé, violinista de origem cubana radicado em Nova lorque. É considerado o responsável por destacar e inovar a forma de tocar o violino no gênero da salsa e da música latina. 
Chega-se ao conceito de timeline elaborado por Ribeiro:

Timeline ou linha guia é o termo empregado para representar uma linha rítmica curta, distinta, de ciclo simples, executada por palmas ou por um instrumento de percussão de timbre agudo que serve como referência temporal em meio a outras linhas rítmicas simultâneas. (...) As timelines caracterizam-se por serem cíclicas e por não admitirem variações. Podem ser chamadas também de bell pattern, topos, clave, referência de fraseado ou linha temporal e podem ser tocadas, por exemplo, por um agogô ou um par de claves. Representam uma camada da textura rítmica que se forma por tambores, chocalhos, palmas de vozes que dão suporte ou criam contraste durante uma performance (RIBEIRO, 2017, p.104).

Uma das principais características da musicalidade afro americana, ela salienta que a timeline "não se trata apenas de um período musical básico estabelecido por um instrumento, mas uma estrutura rítmica moldada que influencia todos os aspectos da música e da dança" (RIBEIRO, 2017, p.104). Essa estrutura rítmica se assemelha a um ostinato, de modo que é executada por meio de uma frase curta com periodicidade invariável, podendo existir duas ou mais através de contraponto. Assim, cada timeline pode se movimentar de forma independente, originando o cross rhythm, que é o cruzamento de padrões rítmicos distintos. Ribeiro afirma que "as timelines caracterizam-se por serem cíclicas e por não admitirem variações" (AROM, 1991 apudRIBEIRO, 2017, p.104) e neste ponto converge com a ideia de um metrônomo. Porém, elas podem ser executadas em qualquer lugar do ciclo:

Uma vez iniciado o ciclo, ele se repete imutável ao longo da peça. Tal limitação é uma das razões pela qual alguns estudos fazem uma analogia entre a timeline como função de metrônomo. Esta analogia não é muito feliz, pois o metrônomo mensura o tempo com unidades repetitivas isócronas e amorfas enquanto que a timeline molda o dimensionamento temporal por séries rítmicas geradas por imparidades de 5 pulsos $(2+3), 7$ pulsos $(2+2+3)$ ou 9 pulsos $(2+2+2+3)$, dispostas em uma ordenação plena de significado (RIBEIRO, 2017, p.109).

A definição dada por Agawu apresentada anteriormente aponta justamente para esta diferença com relação ao metrônomo. Para o autor, o ponto principal está no fato de o metrônomo marcar o tempo ao invés de esculpi-lo, enquanto a timeline usa um ritmo esculpido para marcar o tempo (AGAWU, 2006, p. 7). Desse jeito, "mais que uma pontuação metronômica de tempo: (a timeline) é uma fórmula rítmica/semântica assimétrica que sustenta o tempo de uma música polirrítmica complexa" (RIBEIRO, 2017, p.109). Agregando o pensamento de Leite (2017), a timeline não precisa ser tocada por algum instrumento no contexto da música afro brasileira, uma vez que a melodia e o suporte rítmico/harmônico de acompanhamento já estão in clave, devido à consciência de clave mencionada anteriormente ${ }^{18}$. É algo similar ao que Freitas (2010), ao problema-

180 termo in clave significa estar dentro da clave, ou seja, executar frases musicais inseridas na articulação proposta por uma determinada timeline. Assim, a música já vai estar in clave se for executada com a consciência de clave, sem necessariamente haver um instrumentistatocando a timeline de forma estrita. 
tizar o conceito de síncope, atribui a um modo de expressão musical que não envolve uma questão exclusiva da composição. Segundo ele, "é um componente de interpretação e performance, um tipo de pronúncia ou sotaque que atua também (...) no tecido rítmico dos 'acompanhamentos' destas melodias” (FREITAS, 2010, p. 141).

\section{Álbum "Coisas”}

Foi no cenário plural e culturalmente agitado do Rio de Janeiro da década de 1960 que Moacir Santos organizou as suas "coisas" e lançou seu primeiro LP, em 1965, pelo selo Forma ${ }^{19}$. Fora de catálogo durante décadas, o álbum ganhou versão remasterizada em CD, como afirma Dias: "Mario Adnet e Zé Nogueira, associados ao produtor João Linhares, coordenaram, em 2004, a reedição do LP Coisas em CD remasterizado a partir da fita original, de 1965, e lançado pela Universal" (DIAS, 2010, p.161). Em 2013, a gravadora Polysom relançou o LP "Coisas" em vinil de 180 gramas, pela coleção Clássicos em Vinil. O álbum, com suas dez faixas, é um marco na música instrumental brasileira por conta de sua forte singularidade sonora (FRANÇA, 2007; DIAS, 2010; VICENTE, 2012; BONETTI, 2014). Por possuir grande admiração e encanto pela música de concerto, Moacir Santos quis nomear suas músicas seguindo a tradição clássica do opus, termo latino que significa "obra". Porém, ao invés de chamá-las de "Opus n 1", "Opus n 2", preferiu "Coisa nํ 1", "Coisa n 2" etc. França (2007) teve a oportunidade de entrevistar o compositor em abril de 2006. Sobre o título "Coisas", o compositor comenta:

(...) eu, quando na minha vida de estudos, fiquei muito entusiasmado com a erudição, o clássico... eu fiquei agarrado com a palavra opus. Quando eu cheguei na gravação, a convite do Baden, no estúdio, o moço desceu da ... técnica e disse: maestro, qual é o nome dessa... aí eu disse: isso é uma coisa. Por que? Porque eu gostaria de dizer opus 5, number tal, mas é uma coisa muito elevada para mim. Pelo menos naquela ocasião, naquela época... Mas eu sei que eu estou muito mais maduro, em vez de opus qualquer, no popular, jazz. Mas eu ainda não posso dizer opus, não, porque eu sempre fui admirador do clássico também, a música erudita, quer dizer, desenvolvimento e etc... então é uma coisa: Coisa ํำ1, Coisa $n^{\circ}$ 2... (FRANÇA, 2007, p.142-143).

De acordo com Bonetti $(2014)^{20}$, parte do disco origina-se da trilha sonora composta por Santos para os filmes "Ganga Zumba" e "O Beijo", de Carlos Diegues e Flávio Tambellini, respectivamente, ambos lançados em 1964. Segundo o pesquisador, as "Coisas" de número 4, 5 e 9 são desdobramentos da trilha sonora em "Ganga Zumba"

19 Fundado por Wadih Gebara e Roberto Quartin no Rio de Janeiro, o selo Forma voltava-se à produção e difusão de artistas de pouca projeção no cenário nacional, em oposição às grandes gravadoras Philips, Odeon, RCA e CBS.

20 LucasZangirolami Bonettié criador e produtor do projeto "Trilhas Musicais de Moacir Santos" (Itaú Cultural/FAPESP), quevisa sistematizar, analisar e divulgar as trilhas sonoras compostas por Moacir Santos ao longo de sua carreira em plataforma digital. As transcrições musicais contam com revisão do pianista André Mehmari e inclui depoimentos de Andrea Ernest Dias, Ney Carrasco, Paulo Tiné, Mario Adnet, Moacir Santos Jr., Zé Nogueira, Wynton Marsalis, entre outros. Disponivel em: http:/www.trilhasmoacirsantos.com.br/. 
enquanto as "Coisas" de número 2 e 8 tiveram origem na trilha de "O Beijo". Sobre a trilha sonora de "Ganga Zumba", Dias (2010) explica a sua importância para o processo composicional das "Coisas" (1965):

A trilha sonora de Ganga Zumba antecipou sonoridade que se tornaria a marca característica de Moacir Santos a partir do lançamento do seminal LP Coisas, em 1965, pelo selo Forma. Constam na trilha, além do tema de abertura 'Nanã', os que posteriormente conhecidos como 'Coisa ํo 4', 'Coisa no 9' e 'Mãe Iracema', em instrumentações que variam do tratamento a capella às combinações tímbricas de piccolo, flauta, clarinete, clarone, fagote, saxofone, trombone e percussão, em que predomina a utilização de atabaques e tímpanos. Ganga Zumba funcionou como uma espécie de laboratório para o LP Coisas (grifo meu) (DIAS, 2010, p.107).

Essas e outras "coisas" já vinham sendo anotadas por Santos em um caderno, chamado por Dias de caderno "Pré-Coisas". Observa-se na lista abaixo (Fig. 5) que cada "Coisa" possui um padrão rítmico aplicado à melodia que funciona como mote da composição.

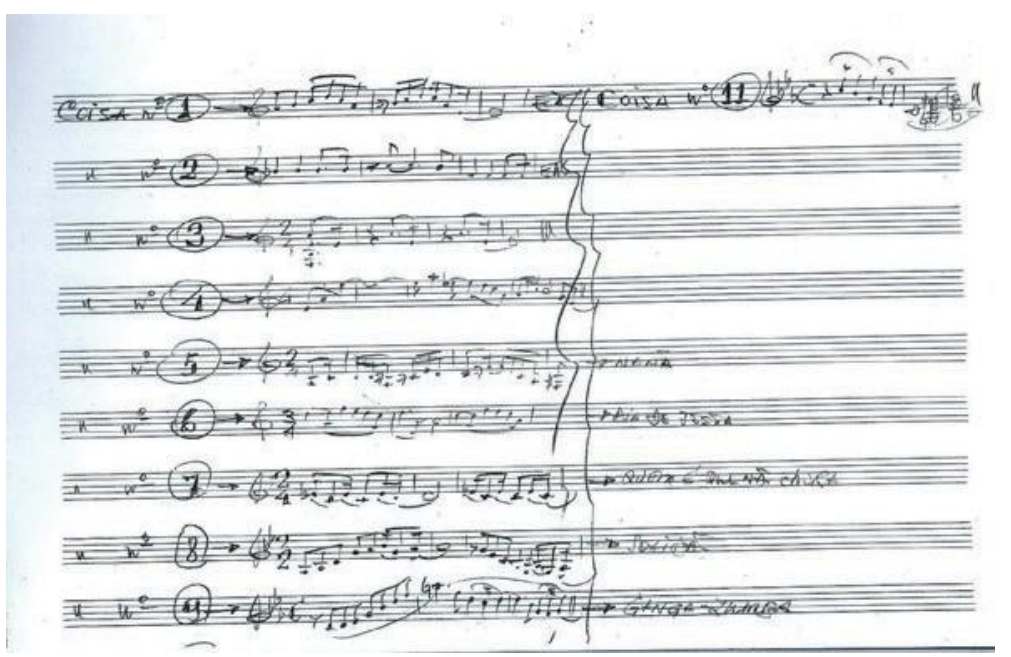

Fig. 5 - Manuscrito de Moacir Santos no caderno "Pré-Coisas". Fonte: Dias (2010).

Esses padrões são oriundos dos "Ritmos MS" juntamente com a influência da diversidade de ritmos afro brasileiros que nortearam o processo composicional de Moacir Santos no álbum "Coisas". Os "Ritmos MS" foram criados pelo músico, com a denominação aludindo às suas iniciais, como um recurso pedagógico e composicional, como será visto mais adiante. Segundo Dias, "trata-se de pequenos padrões rítmicos que, combinados entre si, resultam na criação de motivos ou temas melódicos" (DIAS, 2010, p.77). 


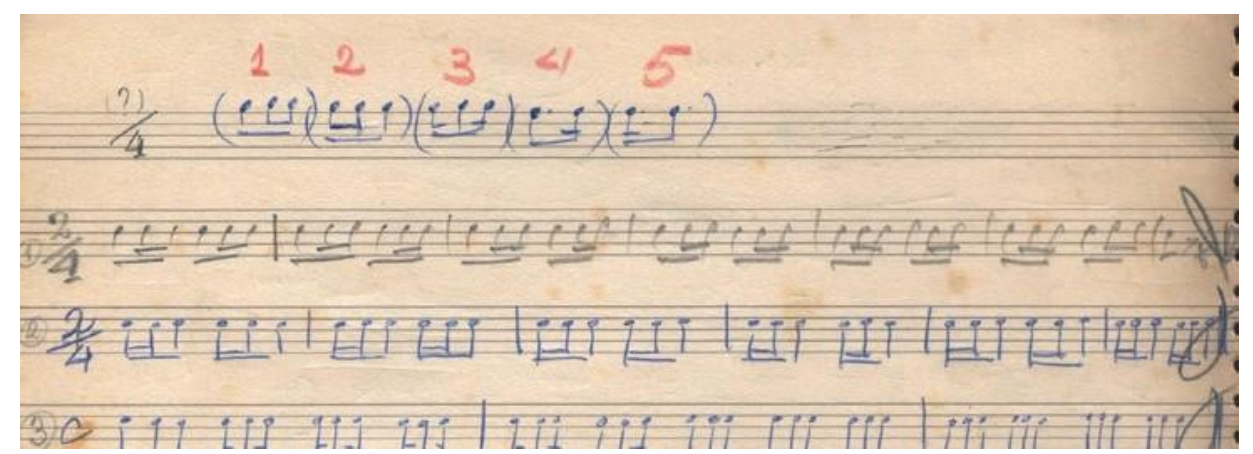

Fig. 6 - Exercícios de combinação dos “Ritmos MS”. Fonte: Dias (2010).

O crítico musical Sérgio Porto (1923-1968), em matéria para o jornal Última Hora, sinaliza para as timelines, ainda que de forma menos técnica, ao tratar da repetição que os instrumentos percussivos executam no primeiro LP do músico pernambucano: "o tom afro das músicas de Moacir é incontestável e sua maneira de fazer de qualquer instrumento, um instrumento de percussão, às vezes de forma exaustiva (grifo meu) (...)". Portanto, as timelines constituem uma ferramenta essencial para a análise das "Coisas" de Moacir Santos, principalmente no que se refere à questão rítmica, que será discutida em detalhe a seguir.

\section{Análise}

As composições do álbum "Coisas" encontram fundamento em alguns exercícios rítmicos que o músico pernambucano criava para seus alunos na década de 1960, no Rio de Janeiro. Moacir Santos ensinou pontos importantes da teoria musical a Baden Powell, por exemplo, e parte desses ensinamentos resultou nos "Afro-sambas", que são um "conjunto de temas modais compostos por Baden Powell a partir dos exercícios de composição sobre os modos gregos que Moacir aplicava em seus cursos, segundo depoimento do violonista" (DIAS, 2010, p.75) ${ }^{21}$. Os "Ritmos MS" faziam parte da estrutura rítmica que Santos ensinava aos seus alunos e o uso que atribuía à combinação desses ritmos pode ser remetido aos conceitos de timeline. A partir de uma motivação composicional, os "Ritmos MS" serviam como orientação rítmica na música, sejam executados por instrumentos melódicos, harmônicos ou percussivos.

Dias (2010) identificou, com auxílio de percussionistas, os ritmos que podem ser associados às composições do álbum "Coisas" e as de número 4, 5 e 9 foram remetidas ao toque de candomblé denominado alujá. No entanto, Lühning (1990), ao se aprofundar na música do candomblé, afirma que o alujá é um ritmo solístico que tem como base uma timeline de 12 pulsações iguais ${ }^{22}$, a qual é identificada por Cardoso (2006)

21 Composto por Baden Powell e Vinícius de Moraes, "Os Afro-sambas" (1966)é um álbum com forte sonoridade de matriz africana, principalmente no que se refere à música de candomblé, atrelada ao samba.

Termo usado por Kubik (1972) para se referir às menores porções rítmicas de uma frase. Na notação utilizada (fig. 7), cada pulsação é repre- 
como vassi (Fig. 7) 23. Agawu (2006) debruça-se sobre esse padrão rítmico, denominado standard pattern pelos pesquisadores, elegendo-o como a principal timelineexecutada na costa ocidental africana e que, consequentemente, foi objeto de análise na maioria das pesquisas já feitas sobre o tema.

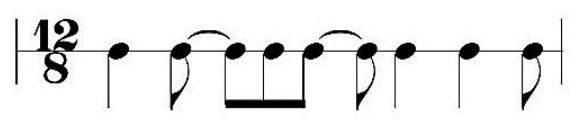

Fig. 7 - Timeline (Vassi).

Essa figuração rítmica remete-se à ideia geral de timeline, pois é executada por um instrumento percussivo agudo (agogô) de maneira cíclica e repetitiva, orientando as variações dos atabaques do candomblé: o rum, rumpi e lé. No entanto, nota-se que o compositor fez uma customização rítmica, visto que as timelines foram criadas por ele mesmo, ainda que faça alusão a esse padrão rítmico. Vicente e Dias comentam:

Das dez Coisas de Moacir Santos, a nํㅜ e nํ10, assim como várias de suas composições têm como referência o toque ijexá para a construção da levada da seção rítmica, em uma concepção não estritamente ligada à linha-guia. As gravações de Coisas (1965) são possivelmente as primeiras a proporem e estilizarem este ritmo dentro no mercado fonográfico brasileiro, que se tornou constante ao longo da produção de Moacir Santos (VICENTE, 2012, p.88).

No plano rítmico, fica clara a opção de Moacir Santos por estilizar os padrões da cultura musical afro-brasileira, dando ao conjunto de Coisas uma caracterização única na sonoridade instrumental dos anos 60 , alcançada tanto pela associação da instrumentação usual das bandas de música e big-bands jazzísticas à percussão típica dessa tradição cultural (atabaques, agogôs, afoxés, etc.) quanto pelo tratamento polirrítmico dispensado ao contraponto (DIAS, 2010, p.14).

No mesmo sentido, França (2007) aponta para a criação da timeline em "Coisa no 5", quando discute a suposta referência do "jongo da Serrinha" na composição:

Enfatizamos, no entanto, que não se pode afirmar que a levada utilizada por Moacir Santos seja retirada da levada do jongo da Serrinha, mas, somente, que são semelhantes. Acreditamos que não haja uma levada única, original, da qual Santos retirou material para uma estilização (grifo meu) e sim que, sendo Moacir Santos um músico profissional atuante desde a infância em diversas cidades do país, que cultivava a música afro-brasileira (...), o material utilizado para a criação

sentada por uma colcheia, necessitando de 12 colcheias para preencher o ciclo da timeline.

23 Segundo Lühning (1990, p. 120), a timeline identificado por Cardoso (2006, p. 260) como vassi, é uma fórmula de organização rítmica que compõe a base de vários ritmos solísticos além do vassi, como a avaninha e o ibí, e é a responsável por acompanhar a maioria das cantigas do candomblé. 
de uma nova levada (grifo meu) vinha do seu arcabouço musical adquirido por sua vivência (...) (FRANÇA, 2007, p.117).

\section{Coisa $N^{\circ} 5$}

Conforme mencionado anteriormente, a "Coisa no 5" possui origem no filme "Ganga Zumba" (1964), de Carlos Diegues. No entanto, na gravação do disco "Coisas" observa-se que ela agrega os seguintes elementos: a seção introdutória aparece no "tema de procissão a Palmares" e as partes A e B, juntamente com a Coda, estão contidas no "tema principal" 24 . Nas aparições do filme, os dois temas possuem, ao todo, a seguinte instrumentação: voz, piccolo, flauta de bambu, clarinete, clarone, trompete, trombone, agogô e atabaque (BONETTI, 2014). Já na versão para o álbum "Coisas", os instrumentos são: flauta, trompete, sax alto, sax tenor, sax barítono, trompa, trombone, trombone baixo, guitarra, contrabaixo acústico e percussão (ADNET; NOGUEIRA, 2005). Posteriormente, a "Coisa no 5 " teve uma versão com letra de Mário Telles que foi intitulada "Nanã" e lançada no álbum "The Maestro" (1972), sem a seção introdutória:

\footnotetext{
Fica claro que Moacir, para compor a versão da "Coisa no 5" presente no álbum Coisas, utilizou o material composicional de dois fragmentos diferentes de sua trilha para Ganga Zumba. A introdução foi desenvolvida por meio do "tema da procissão a Palmares" e o corpo principal da música a partir do "tema principal". Já a composição de "Nanã", presente no disco The Maestro de 1972, só se baseia no "tema principal" (BONETTI, 2014, p.283).
}

Moacir Santos escreve no encarte do CD "Ouro Negro": "Fico muito feliz de vocês terem gravado a versão original, porque foi assim que ouvi e assim que fiz. É uma grande procissão" (SANTOS, 2001, p.17). Em depoimento nas gravações do DVD "Ouro Negro" (2005), o músico comenta que a música foi pensada a partir de uma procissão de negros ${ }^{25}$. Nessa mesma ocasião, é ressaltado o caráter binário da composição, quando Zé Nogueira e Moacir Santos cantam a melodia da parte A e marcam o tempo com as mãos. No "Caderno Pré-Coisas", a anotação para a trilha de "Ganga Zumba" revela o compasso binário simples (2/4) na melodia principal e o compasso binário composto (6/8) na parte intitulada "ritmo".

24 Estas denominações temáticas foram dadas por Bonetti (2014).

25 Depoimento contido em trecho extraído do DVD “Ouro Negro”, em que Moacir Santos conversa com Mário Adnet e José Nogueira. Disponível em: https:/www.youtube.com/watch?v=gVeE7WZG_IY. Acesso em: 23 out, 2019. 


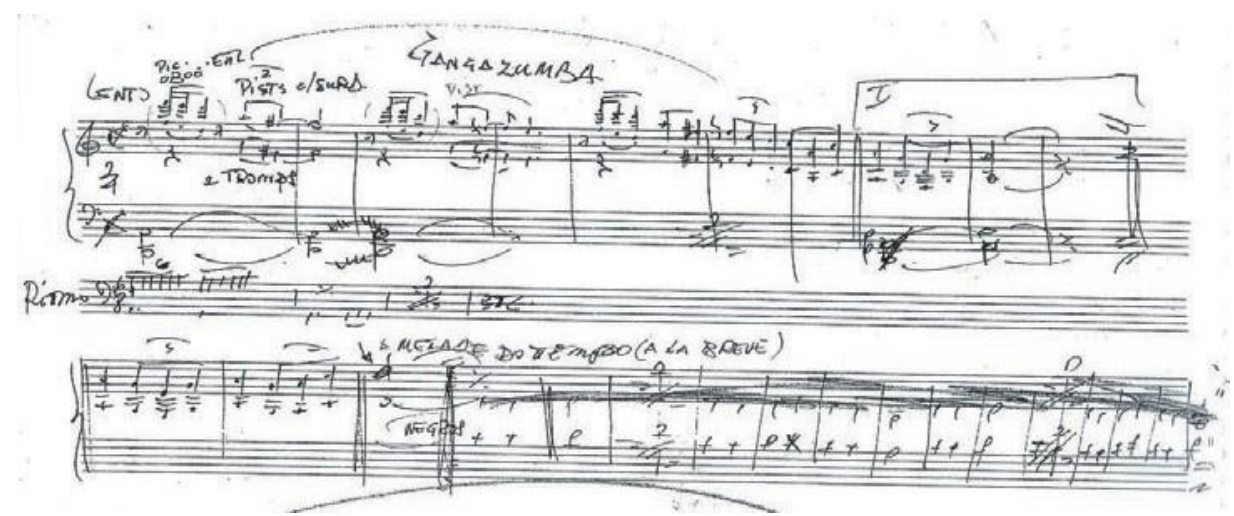

Fig. 8 - Anotações para a trilha sonora de "Ganga Zumba" (1965). Fonte: Dias (2010).

Entretanto, no livro de partituras "Coisas: Cancioneiro Moacir Santos"(2005), que contou com revisão do próprio compositor, a música está escrita toda em compasso binário composto (6/8), por isso, esta configuração será mantida na presente análise. De acordo com Bonetti, "essa ambiguidade se dá pois ao se sobrepor os planos rítmicos simples e composto o compositor (ou transcritor) pode escolher se basear em qualquer um deles, utilizando quiálteras para encaixar a rítmica diferente" (BONETTI, 2014, p.65).

$\mathrm{Na}$ metade da seção introdutória, é revelada a sonoridade resultante da combinação entre melodia principal (flauta, trompete, sax alto e sax tenor), miolo (trompa e trombone), ostinato (sax barítono, trombone baixo e contrabaixo) e percussões.

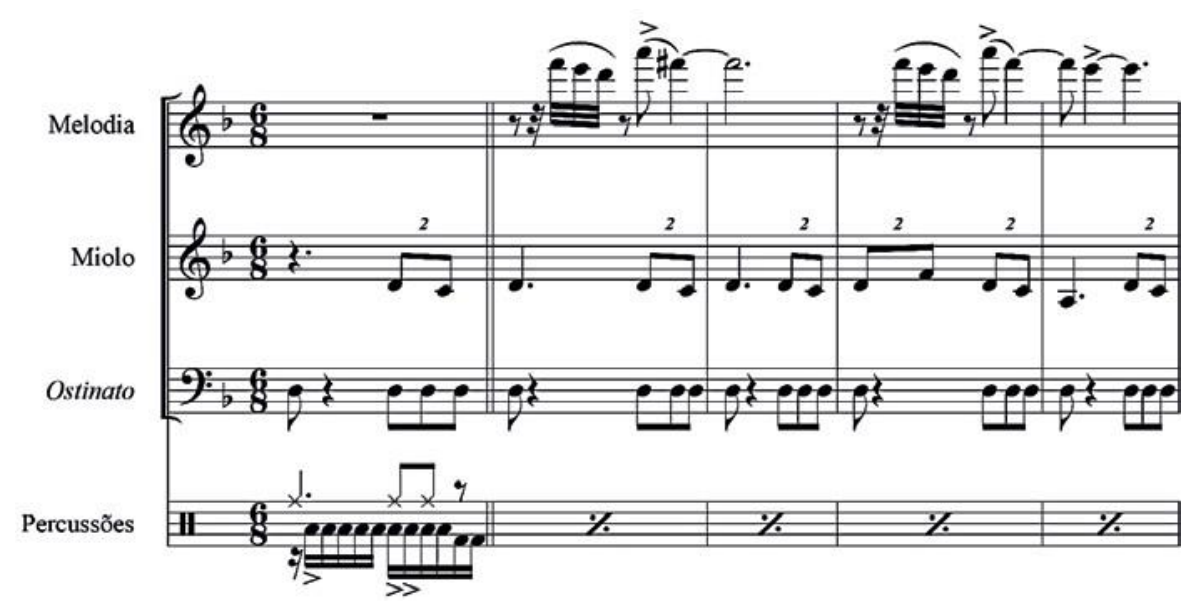

Fig. 9 - "Coisa $n^{\circ} 5^{" ~}$ redução da textura da seção introdutória.

O miolo executa duínas (quiálteras de dois tempos em compasso composto) em contraste com a divisão do ostinato. 


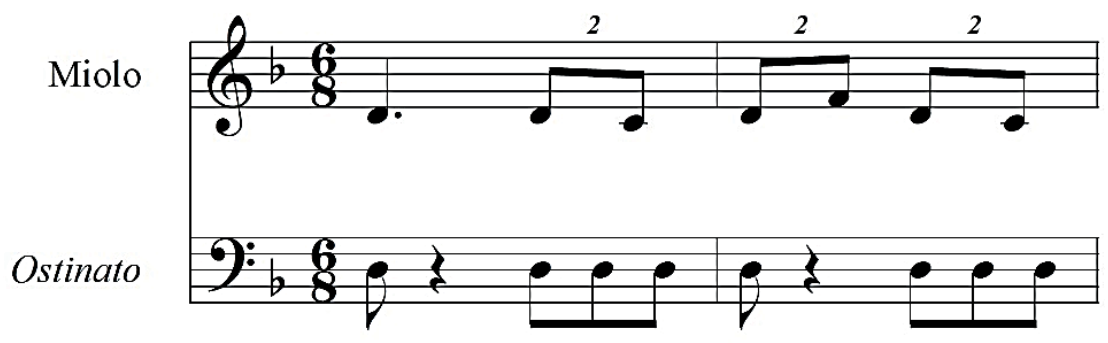

Fig. 10 - "Coisa n 5" hemíola na seção introdutória.

Moacir Santos comenta em entrevista a França: "Tem uma coisa chamada hemíola. (...) eu uso muito hemíola, o dois para três" (FRANÇA, 2007, p.141). Trata-se de um fenômeno rítmico em que há uma coexistência de dois e três pulsos no mesmo intervalo de tempo ou, como afirmam Cooper e Meyer, "no qual a oposição de três grupos tocados contra dois grupos de três $(2+2+2 / 3+3)$ é resolvido depois de seis tempos" (COOPER; MEYER, 1960 apudVICENTE, 2012, p.93). Sobre a “Coisa n 5", Dias ressalta que "o plano rítmico é todo estruturado na perspectiva polirrítmica, justapondo agrupamentos binários a ternários (grifo meu), (...) uma das características do mundo sonoro afro-ocidental" (DIAS, 2010, p.213). Finalmente, Ribeiro comenta:

Uma vez que um compasso $3 / 4$ e o compasso 6/8 têm o mesmo número de colcheias, é possível mudar o agrupamento binário de três colcheias para um agrupamento ternário de duas colcheias. Esta troca entre binários e ternários no mesmo nível métrico, chamada ocidentalmente de hemíola (grifo meu) (...) (RIBEIRO, 2017, p.98).

A marcação feita pelo ostinato e pelo agogô apontam para a formação de uma timeline na introdução da música. Conforme mencionado anteriormente, pelo fato de ser um instrumento percussivo de timbre agudo que possui linha rítmica cíclica repetida ao longo da música, o padrão rítmico do agogô é priorizado nesta parte como orientador rítmico.

Ostinato

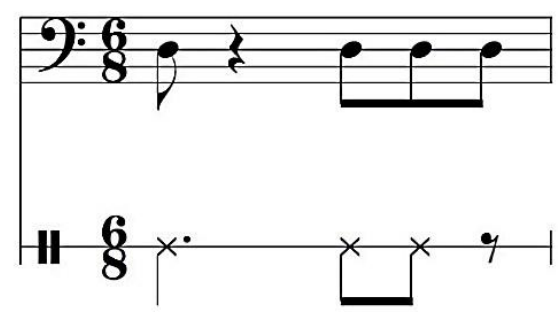

Fig. 11 - "Coisa n ${ }^{5}$ " timeline na seção introdutória.

No final da seção introdutória, o Ritmo MS 1 (colcheia + duas semicolcheias - Fig. 6) está presente na caixa clara. Em 6/8, este ritmo gera um efeito de hemíola, pois é articulado três vezes em doistempos. 


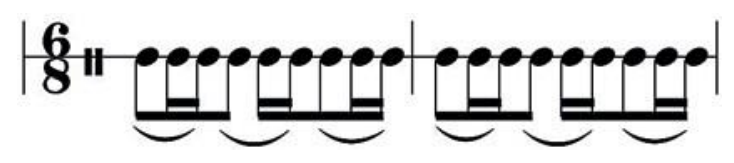

Fig. 12 - "Coisa n 5" Ritmo MS 1 na caixa clara (compassos 20 e 21).

Reescrevendo esse trecho em 3/4, o Ritmo MS 1 torna-se mais evidente.

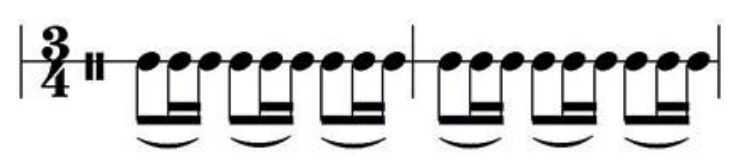

Fig. 13 - "Coisa no 5" Ritmo MS 1 em 3/4.

Mais adiante, entretanto, a acentuação executada pela caixa clara remete ao Ritmo MS 2 (duas semicolcheias + colcheia, ou seja, uma inversão do Ritmo MS 1).

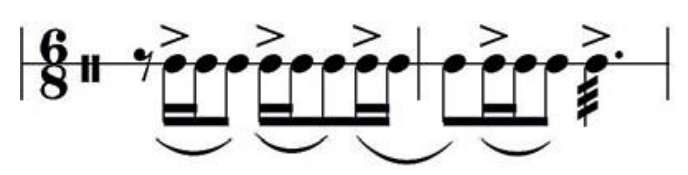

Fig. 14 - "Coisa n 5" Ritmo MS 2 e timeline na caixa clara (compassos 22 e 23).

Esta unidade é repetida quatro vezes, finalizando com um quinto ataque do rulo no segundo compasso. É importante atentar para a seguinte observação: em dois compassos binários compostos (somando quatro tempos no total), com a subdivisão de três colcheias em cada tempo, há cinco acentuações na execução da caixa, sendo que a última rompe com a regularidade dos motivos. Esse padrão rítmico se mantém durante quase toda a música e pode ser considerado uma timeline, pois, além de ser executado por um instrumento percussivo agudo, tem uma irregularidade interna. Assim, ele também pode ser encarado como orientador rítmico na composição, sobretudo porque o último ataque na caixa contraria a duração regular dos anteriores. Fazendo uma redução do padrão rítmico da Figura 17 com base nas acentuações, obtém-se a seguinte timeline:

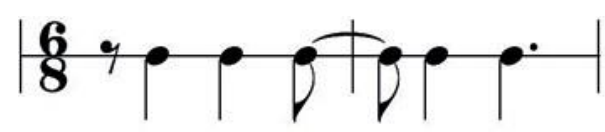

Fig. 15 - "Coisa n 5" redução da timeline (compassos 22 e 23). 
A parte $A$, enfoque desta análise, é formada por uma frase melódica de oito compassos com um desenho periódico, ou seja, uma ideia básica de dois compassos seguida por uma ideia contrastante, executada pelo sax barítono e trombone.
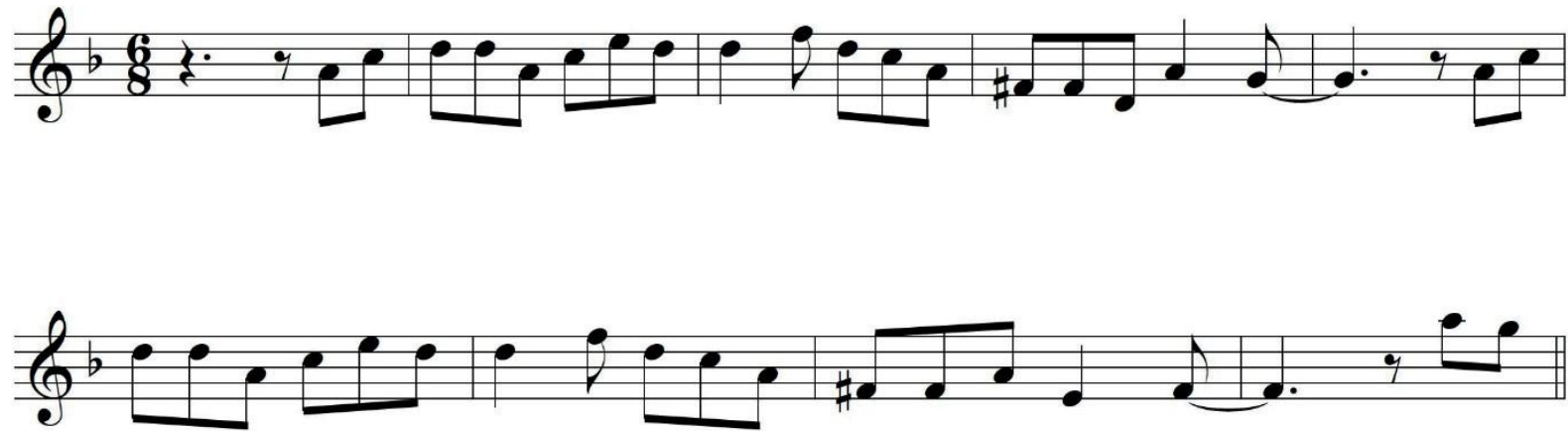

Fig. 16 - "Coisa $n^{\circ} 5^{\prime \prime}$ melodia principal - parte A.

Em uma primeira versão, a "Coisa no 5" foi escrita em 2/4, como se pode comprovar nos esboços contidos no "Caderno Pré-Coisas" do compositor (ver Fig. 5). Com a finalidade de comparar a escrita das duas versões, as figuras abaixo mostram o trecho inicial da melodia no "tema principal" e na parte A da "Coisa $n^{\circ} 5^{5}$ em $2 / 4$ e 6/8, respectivamente ${ }^{26}$. Além das fórmulas de compasso, é importante também perceber as diferenças rítmicas entre as duas frases melódicas ocasionadas por diferentes padrões rítmicos no acompanhamento, que funcionam como um molde que esculpe a melodia (AGAWU, 2006; AGAWU, 2017).

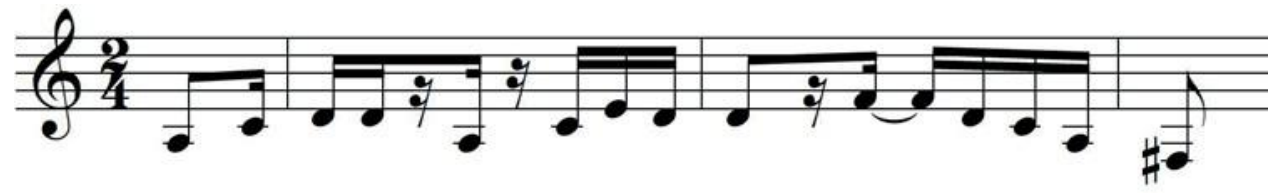

Fig. 17 - "Coisa n ${ }^{\circ}$ " tema principal em 2/4.

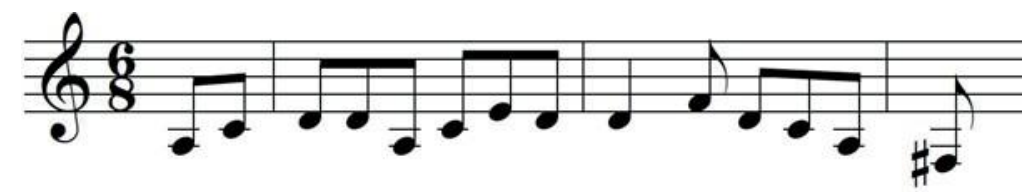

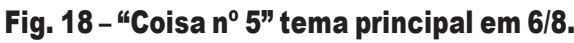

A melodia principal da parte A (Fig. 16) é moldada pela interação do miolo com o ostinato na seção rítmica, presente na figura abaixo. Desta vez o miolo é executado pelo trompete, saxofones alto e tenor, trompa e guitarra (que condensa as quatro vozes dos sopros) enquanto o ostinato é composto somente pelo trombone baixo e contrabaixo.

26 As melodias das Figuras 17 e 18 encontram-se uma oitava abaixo em comparação à melodia presente na Figura 16. 
Esta ideia possui uma unidade de dois compassos que é repetida cinco vezes.

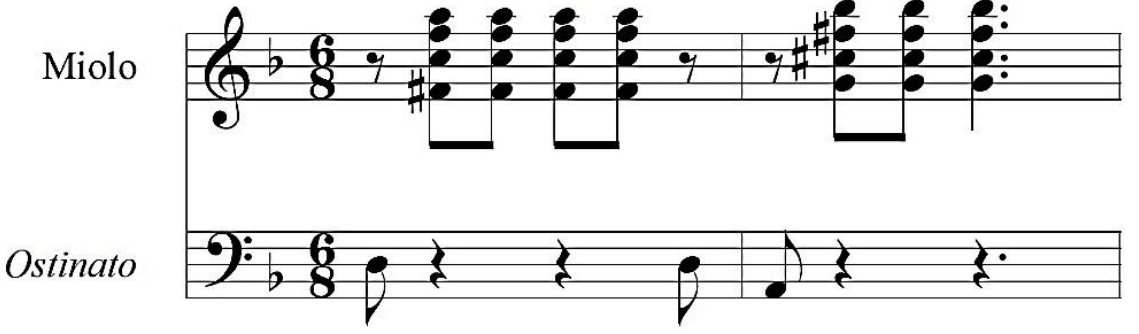

Fig. 19 - "Coisa n $^{\circ}$ " interação entre miolo e ostinato.

Para esclarecer, observa-se que a primeira parte da melodia (Fig. 18), composta pelas primeiras 9 notas, já revela o molde firmado pela interação acima (Fig. 19). A figura abaixo reúne o curto trecho da melodia principal e seu acompanhamento (miolo + ostinato ${ }^{27}$. Com isso, contata-se que o acompanhamento funciona como uma timeline, na medida em que esculpe a melodia.

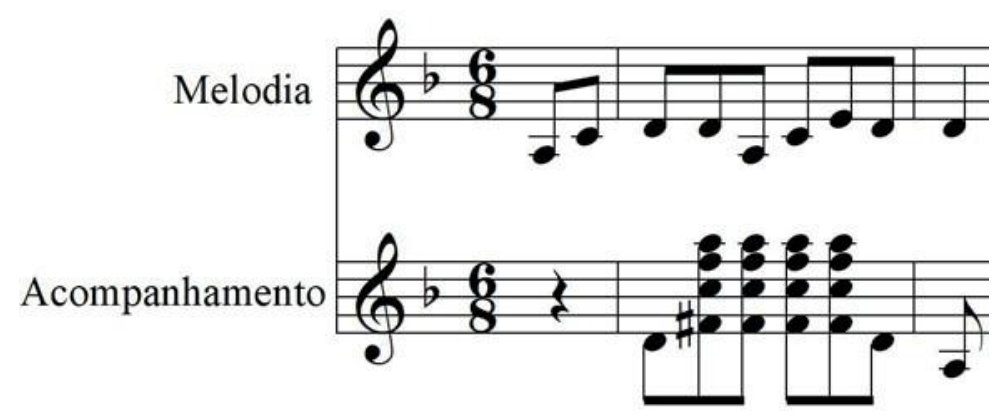

Fig. 20 - "Coisa n 5" início da melodia principal e acompanhamento

Em uma visão vertical, constata-se que os padrões rítmicos da Figura 19 se complementam. É possível relacionar aquela figuração com o mojo, que é "uma nova estilização rítmica de concepção pessoal, (...) levada criada pelo compositor (Moacir Santos) que se tornou conhecida no meio musical" (FRANÇA, 2007, p.90) ${ }^{28}$. Segundo Dias, ao criar "um jogo contrapontístico entre graves e agudos (grifo meu), o compositor faz com que os instrumentos melódicos e harmônicos também participem da ideia percussiva que constitui o mojo" (DIAS, 2010, p.175). Certamente, o mojo é um traço marcante da sonoridade de Santos. Em entrevista a França, ele conta sobre a sua criação:

E: Sobre a fase dos Estados Unidos, o Sr. criou um ritmo que é chamado de Mojo...

M: Eu cheguei lá nos Estados eu vi um ritmo... então eu criei o Mojo, eu inventei

27 Para facilitar a visualização na Fig. 20, o acompanhamento está escrito na clave de sol e a parte do ostinato (graves) está uma oitava acima.

28 Na cultura afro americana, mojoé um pequeno objeto ou bolsa que representa magia, feitiço ou amuleto. Geralmente, é utilizado na prática do hoodoo ou voodoo. 
essa palavra: Mojo [...] vindo do negro americano.

$\mathrm{E}$ : O Sr. criou esse ritmo porque os músicos americanos tinham dificuldade de tocar samba?

M: Não, criei por vaidade mesmo, porque ouvi uma expressão negroide, da África. O negro foi espalhado pelo mundo inteiro. Então, naturalmente, o negro americano veio da África. Ele é diferente, anda diferente. Então eu inventei uma coisa diferente também, como um negro brasileiro, semi-americano (FRANÇA, 2007, p.144).

Em uma redução incluindo o miolo e o ostinato em uma mesma pauta, percebe-se mais claramente a relação com o mojo através de duas alturas: uma grave (ostinato)e outra aguda (miolo). Vale ressaltar que o exemplo abaixo representa uma das várias figurações possíveis do mojo.

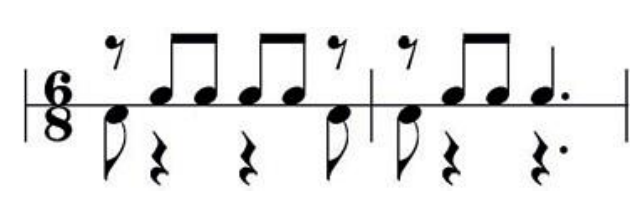

Fig. 21 - "Coisa n 5" mojo.

Na figura abaixo, verifica-se que a redução da timeline da caixa clara (Fig. 18) está presente no mojo através das acentuações. Assim, de certa maneira o mojo pode ser visto como uma variação desta timelinereduzida.

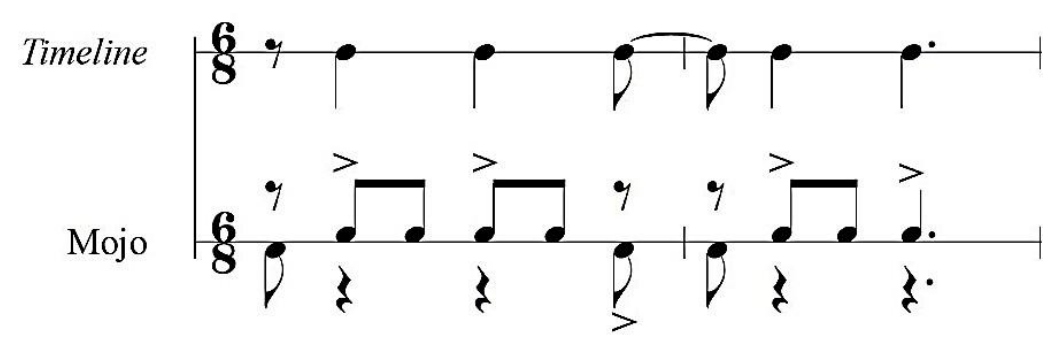

Fig. 22 - "Coisa n 5" timeline x mojo.

A figura abaixo mostra as interações e os contrastes entre o miolo, o ostinato e a caixa clara na parte A. Dessa maneira, observa-se de forma vertical momentos de complementariedade e de sobreposição na textura do acompanhamento elaborado pelo compositor, servindo de base para a melodia principal na parte A em "Coisa nํ5". 


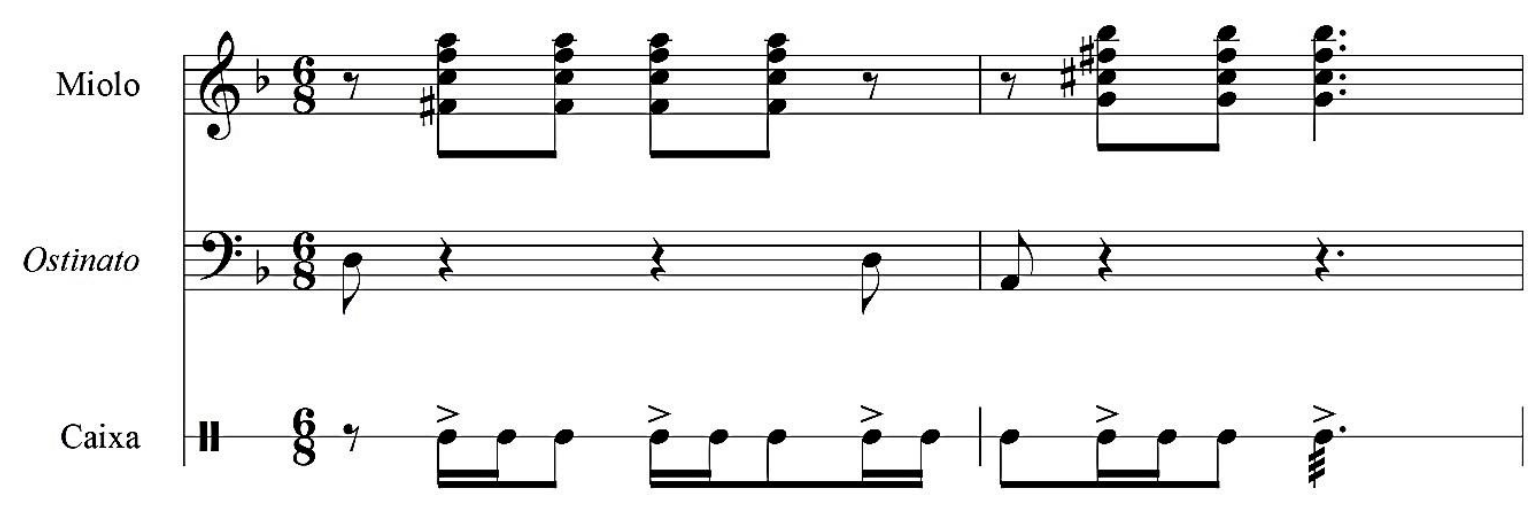

Fig. 23 - “Coisa n 5" seção rítmica.

\section{Considerações Finais}

Este trabalho teve como objetivo principal analisar o aspecto rítmico em "Coisa $n^{\circ}$ 5", de Moacir Santos, tendo com base a timeline como ferramenta metodológica. Procurou-se demonstrar como a música de matriz africana, especificamente da costa ocidental, está presente na obra de Moacir Santos por meio de sua estrutura rítmica. Através de uma ampla discussão sobre timeline, suas definições e implicações, este artigo propôs contextualizar e problematizar a formulação conceitual elaborada por um viés unicamente estrutural, que não considera as questões sociais, históricas e culturais que envolvem as timelines e, por conseguinte, as práticas musicais do oeste africano. Assim, foi possível constatar a pluralidade nos conceitos, descartando uma visão definitiva sobre timeline, que se encontram em um processo de construção marcado por discordâncias e disputas. Assim como a timeline, outros conceitos elaborados pela musicologia de herança europeia foram concebidos pela lógica da regularidade supostamente encontrada no repertório tradicional da Europa. Diante disso, a questão passa a ser cultural também, pois manifestações musicais não europeias são classificadas como irregulares, fugitivas do padrão (AGAWU, 2006; FREITAS, 2010; LEITE, 2017; MENEZES, 2018). O texto da primeira parte deste trabalho foi calcado numa abordagem crítica ao eurocentrismo presente na temática.

Em seguida, houve um aprofundamento analítico na relação das timelines presentes no acompanhamento com a melodia principal em "Coisa no 5", enfocando a parte A da peça. $O$ olhar vertical sob as linhas instrumentais foi fundamental para a percepção dos contrastes musicais articulados pelo compositor e das texturas polirrítmicas. Foi interessante notar, especificamente, como Moacir Santos engendrou duas esferas de interação rítmica na peça analisada. A primeira é composta pela melodia principal e seu acompanhamento executado por toda a seção rítmica. Nela, foram observadas as questões principais a serem comprovadas nesta pesquisa, relativas à estruturação rítmica da peça, em que o acompanhamento exerce o papel de timeline ao moldar, basear 
e/ou esculpir a melodia (Fig. 20). Já a segunda esfera de interação acontece dentro da seção rítmica, ou seja, é formada por suas relações internas entre o miolo, ostinato e caixa (Fig. 23). Em resumo, a melodia principal é esculpida por um acompanhamento já esculpido internamente. Em um primeiro momento de audição, o ouvinte tende a perceber a seção rítmica de forma fragmentada, sem assimilar suas relações internas, e posteriormente o entendimento mais amplo começa a serfeito.

É nesse sentido que esta investigação aponta para resultados concernentes à customização feita por Moacir Santos em "Coisa nํ 5" ao criar as esferas de interação descritas acima em seu processo composicional, construindo uma sólida estrutura rítmica, principalmente na parte $A$. As análises indicam que a customização dos padrões rítmicos pode ser atribuída ao papel que as timelines cumprem na música da costa ocidental africana, na medida em que orienta a estrutura rítmica, principalmente no que se refere à relação da melodia principal com o seu acompanhamento.

\section{Referências}

ADNET, Mário; NOGUEIRA, José. Coisas: cancioneiro Moacir Santos. Rio de Janeiro: Jobim Music, 2005.

AGAWU, Kofi. Structural Analysis or Cultural Analysis? Competing Perspectives on the "Standard Pattern" of West African Rhythm. Journal of the American Musicological Society, v. 59, n. 1. California, USA: University of California Press, p. 1-46, 2006.

AGAWU, Kofi. How We Get Out of Analysis, and How to Get Back In Again. Music Analysis, 23/ii-iii. Oxford, UK: Blackwell Publishing Ltd., p. 267-286, 2005.

AGAWU, Kofi. The African Imagination in Music. Oxford, UK: Oxford University Press, 2016.

AGAWU, Kofi. Palestra denominada Rhythmic Imagination in African Music.

Washington: Library of Congress, 2017. Disponível em: https://www.youtube.com/ watch?v=uyRG9T7CGt8\&t=2619s. Acesso em: 30 mar. 2019.

AROM, Simha. African Polyphony and Polyrhythm: Musical Structure and Methodology. Cambridge: Cambridge University Press, 1991.

BONETTI, Lucas Zangirolami. A trilha musical como gênese do processo criativo na obra de Moacir Santos. Dissertação (Mestrado em Música) - Programa de PósGraduação em Música do Instituto de Artes, Universidade Estadual de Campinas, Campinas, 2014.

CARDOSO, Ângelo Nonato Natale. A linguagem dos tambores. Tese (Doutorado em 
Música) - Escola de Música, Universidade Federal da Bahia, Salvador, 2006.

DIAS, Andrea Ernest. Mais "coisas" sobre Moacir Santos, ou os caminhos de um músico brasileiro. Tese (Doutorado em Música) - Escola de Música, Universidade Federal da Bahia, Salvador, 2010.

FRANÇA, Gabriel Muniz Improta. Coisas: Moacir Santos e a composição para seção rítmica na década de 1960. Dissertação (Mestrado em Música) - Programa de PósGraduação em Música, Universidade Federal do Estado do Rio de Janeiro, Rio de Janeiro, 2007.

FREITAS, Sérgio Paulo Ribeiro de. A memória e o valor da síncope: da diferença do que ensinam os antigos e os modernos. Revista Per Musi, Belo Horizonte, n. 22, p. 127-149, 2010.

GOMES, Fábio Lima Marinho. Timelines em algumas "Coisas" de Moacir Santos. 98 f. Monografia (Bacharelado em Música Popular) - Faculdade de Artes do Paraná, Campus Curitiba II, Universidade Estadual do Paraná, Curitiba, 2019. Disponível em: https://www.academia.edu/41349059/Timelines_em_algumas_Coisas_de_Moacir_ Santos. Acesso em abril, 2020.

JONES, Arthur Morris. Studies in African Music. London, UK: Oxford University Press, 1959.

KUBIK, Gerhard. Oral Notation of Some West and Central African Time-Line Patterns. Review of Ethnology, vol. 3, n. 22, 1972.

LEITE, Letieres. Rumpilezzinho laboratório musical de jovens: relatos de uma experiência. Salvador: LeL Produção Artística, 2017.

LÜHNING, Angela. Música: coração do candomblé. Revista USP, São Paulo, n. 7, setnov., p. 115-124, 1990.

MENEZES, Enrique Valarelli. Transformação de padrões centro-africanos no samba urbano do Rio de Janeiro: 1933-1978. Revista do Instituto de Estudos Brasileiros, Brasil, n. 70 , p. $78-103,2018$.

NKETIA, Joseph Hanson Kwabena. African music in Ghana. Evanston, IL: Northwestern University Press, 1963.

OLIVEIRA PINTO, Tiago de. As cores do som: estruturas sonoras e concepção estética na música afro-brasileira. África: Revista do Centro de Estudos Africanos, São Paulo, USP: p. 87-109, 1999/2000/2001. 
PORTELLA, Juvenal. Discos Populares: Moacir Santos. Jornal do Brasil, Rio de Janeiro, 16 set. 1965. Caderno B, p. 22.

PORTO, Sérgio. Discos: Coisas de Moacir Santos. Última Hora, Rio de Janeiro, 11 out. 1965. Número 1649, p. 40.

RIBEIRO, Bianca. Do tactus ao pulso: a rítmica de Gramani na confluência do tempo sentido e medido. Dissertação (Mestrado em música) - Programa de Pós-Graduação em Música, Centro de Artes, Universidade do Estado de Santa Catarina, Florianópolis, 2017.

SANDRONI, Carlos. Feitiço decente: Transformações do samba no Rio de Janeiro (1917-1933). Rio de Janeiro: Jorge Zahar, 2001.

SANTOS, Moacir. Coisas. Rio de Janeiro: Forma, 1965. Disco em vinil, estéreo.

SANTOS, Moacir. Ouro Negro. Rio de Janeiro: Som Livre, 2001. 2 discos compactos digitais, estéreo.

VICENTE, Alexandre Luís. Moacir Santos, seus Ritmos e Modos: "Coisas" do Ouro Negro. Dissertação (Mestrado em Música) - Programa de Pós-Graduação em Música, Centro de Artes (CEART), Universidade do Estado de Santa Catarina, Florianópolis, 2012 